\title{
Taxonomic Study of Helically Coiled, Sporeforming Anaerobes Isolated from the Intestines of Humans and Other Animals: Clostridium cocleatum sp. nov. and Clostridium spiroforme
}

sp. nov.

\author{
CHOJI KANEUCHI, ${ }^{1}$ TOSHIMITSU MIYAZATO, ${ }^{2}$ TOSHIHARU SHINJO, ${ }^{2}$ \\ AND TOMOTARI MITSUOKA'
}

The Institute of Physical and Chemical Research, Wako, Saitama 351,' and Miyazaki University, Miyazaki 880, Japan ${ }^{2}$

Thirty-three anaerobic, gram-positive, helically coiled microorganisms, of which 26 were freshly isolated from the intestinal contents of humans, mice, rats, and chickens, were the subjects of a taxonomic study. These and 48 freshly isolated Clostridium ramosum-like, noncoiled organisms were found to belong to the genus Clostridium because of their sporeforming ability. They were divided into five groups on the basis of numerous biochemical properties, the guanineplus-cytosine $(\mathrm{G}+\mathrm{C})$ contents of their deoxyribonucleic acids, and their deoxyribonucleic acid homologies. Strains of group I had straight cells and a G+C content of about $28 \mathrm{~mol} \%$ and were identified as members of $C$. ramosum. Cells of the strains in the other groups were coiled. The strains of group II had a G+C content of about $28 \mathrm{~mol} \%$ and were regarded as belonging to a new species, Clostridium cocleatum, of which strain I50 (= ATCC $29902=$ NCTC 11210 ) is designated the type strain. Those of group III had a G+C content of about $27 \mathrm{~mol} \%$ and were placed in Clostridium spiroforme sp. nov., of which strain VPI C28-23-1A (= ATCC $29900=$ NCTC 11211) is designated the type strain. The single strain of group IV, VPI C22-44-2 (Eubacterium AQ of Moore and Holdeman), had a G+C content of $35.8 \mathrm{~mol} \%$ and was regarded as a new but unnamed organism in the genus Clostridium. Those of group V, including the original strains of this sort reported by Fitzgerald et al., had a $\mathrm{G}+\mathrm{C}$ content of about $46 \mathrm{~mol} \%$ and were also considered to be a new but unnamed organism in the genus Clostridium.

An anaerobic, gram-positive, helically coiled microorganism from the cecum of rats was first reported by Bladen et al. (1) in 1964. Fitzgerald et al. (4) studied similar strains in detail and identified them as members of Eubacterium. A number of similar organisms have been isolated from the feces and intestines of humans and other animals $(6,8,18,19,26,34)$ and from a case of human abdominal abscess (30). Most of these strains have been considered to be nonsporeformers (Eubacterium) $(1,4,6,26,30,34)$. Recently, however, Koopman et al. $(18,19)$ observed in vivo spore formation with the strains from mice. Hazenberg et al. (8) identified their strains from mice as members of Clostridium ramosum.

In the course of studies on the intestinal flora of humans and other animals, a number of strains that appear to be closely related to the above-mentioned coiled organisms were isolated. Some of these isolates were found to have spores; this was an indication that they were clostridia. They were also found to share a number of features in common with C. ramosum. A study was undertaken, therefore, to determine the systematic positions of the previously reported coiled organisms and of the fresh isolates, in particular with respect to C. ramosum $(9,10$, 32).

\section{MATERIALS AND METHODS}

Bacterial strains. The 84 strains studied and their sources are listed in Table 1 . Of these, 33 were coiled organisms isolated from the feces of healthy men or from the cecal contents of mice, rats, or chickens (including the original strains of Fitzgerald et al. [4]); 48 were fresh isolates which had straight cells and resembled $C$. ramosum; and the remaining 3 were $C$. ramosum strains ATCC 25582 (neotype strain), VPI 8546, and VPI 4496A, used as references. VPI 4496A was formerly identified as a strain of Eubacterium filamentosum, a name which has been shown to be synonymous with $C$. ramosum (10).

Isolation of strains and maintenance of cultures. Fecal and cecal samples diluted in an anaerobic buffer solution were plated out on modified EggerthGagnon (EG) agar (25), glucose-blood-liver (BL) agar (25), and medium 10 agar (3). Medium 10 agar was supplemented with $1 \%$ (wt/vol) fresh mouse feces and 
TABLE 1. Strains used in this study

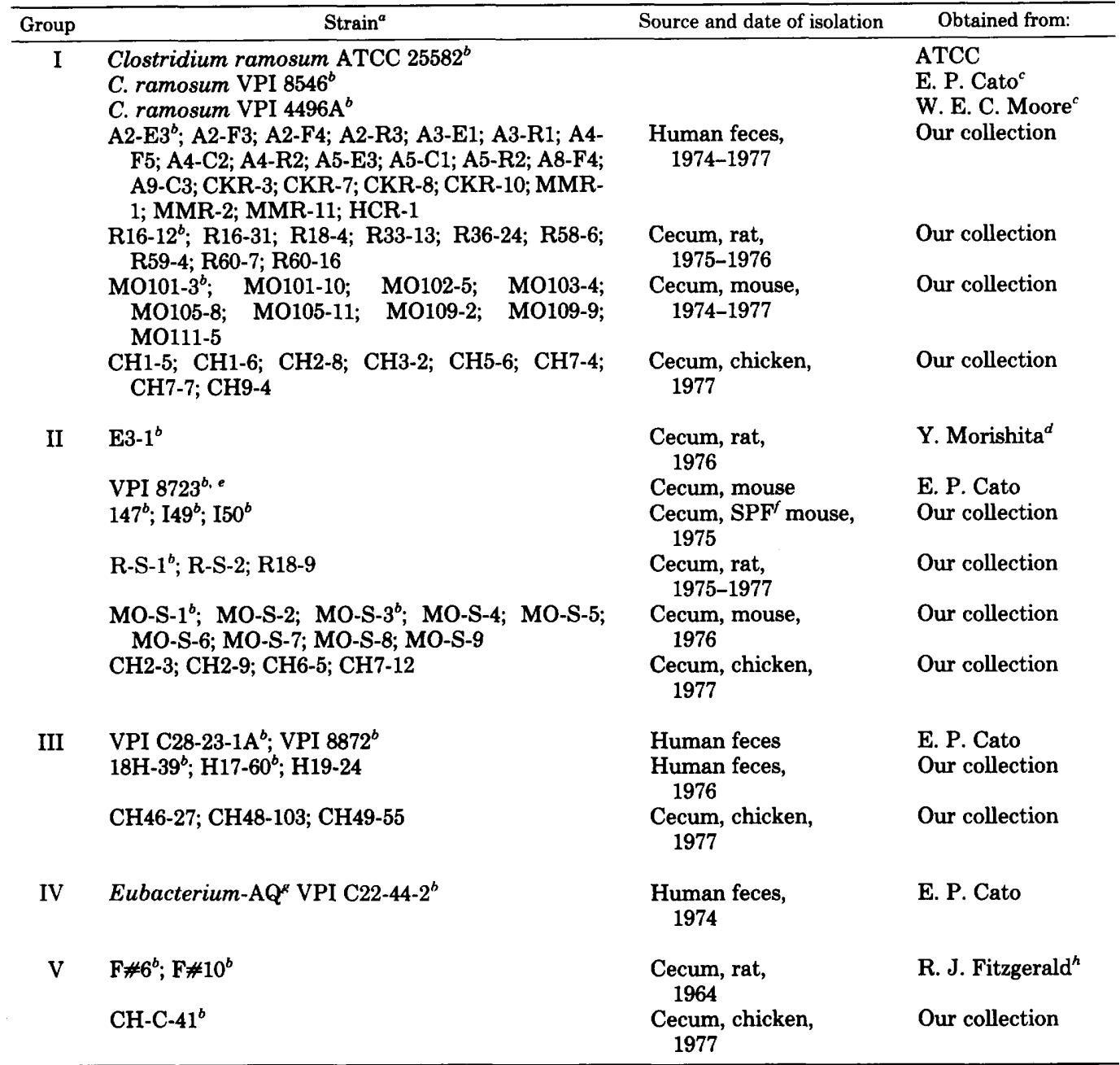

${ }^{a}$ ATCC, American Type Culture Collection, Rockville, Md.; VPI, Virginia Polytechnic Institute and State University, Blacksburg, Va.

${ }^{b}$ Strains for which $\mathrm{G}+\mathrm{C}$ contents were determined in this study.

c Virginia Polytechnic Institute and State University, Anaerobe Laboratory, Blacksburg, Va.

${ }^{d}$ National Institute of Health, Tokyo, Japan.

e Originally isolated by F. Wensinck, Laboratory of Medical Microbiology, Medical Faculty, Rotterdam, The Netherlands.

'Specific pathogen free.

Reference 26.

${ }^{h}$ Veterans Administration Hospital, Miami, Fla.

was prepared "plate-in-bottle" fashion (24). Decimal dilutions of most samples were also plated on the three media after they had been either heated at $70^{\circ} \mathrm{C}$ for $10 \mathrm{~min}$ or treated for $2 \mathrm{~h}$ with ethyl alcohol added to give a final concentration of $80 \%$ (vol/vol) (7) or for 1 $h$ with chloroform added to give a final concentration of $0.02 \%$ (vol/vol). EG and glucose-blood-liver agar plates were incubated at $37^{\circ} \mathrm{C}$ in an anaerobic steelwool jar (29) filled with an atmosphere of $90 \% \mathrm{~N}_{2}$ and $10 \% \mathrm{CO}_{2}$. After incubation for 3 days, all colonial types were picked onto EG agar or medium 10 agar. Gram- positive, curved or coiled organisms and C. ramosumlike organisms were selected. Strains were maintained on prereduced EG liver agar slants (with $\mathrm{H}_{2} \mathrm{CO}_{3}-\mathrm{CO}_{2}$ buffer) (25) stored at $4^{\circ} \mathrm{C}$. New transfers were usually made at 3-month intervals.

Cultural and biochemical tests. The methods for cultural and biochemical characterization of the strains used in this study were described previously (16). $\beta$-Glucuronidase activity was tested by the method of Kent et al. (17) with a partial modification. Lecithinase activity was detected in peptone-yeast 
extract-Fildes solution (PYF) broth (16) with $0.2 \%$ (wt/vol) glucose and 5\% (vol/vol) fresh egg yolk added. Lipase activity was tested in PYF deep agar $(0.5 \%$ [wt/ vol] agar) with $1 \%$ (vol/vol) glycerol tri- $n$-butyrate added (12). A positive reaction was detected by a zone of clearing along the stabs.

Spore formation test. Organisms were grown on the surfaces of chopped-meat (CM) agar slants (10) and medium 10 agar at $30^{\circ} \mathrm{C}$ and stained at intervals of 5 to 7 days during a 4-week period by the Gram stain (Hucker) (13) or the spore stain (Wirtz) (13). In addition, prereduced PYF starch broth in rubber-stoppered tubes (16) was inoculated with growth from CM agar slants or medium 10 agar (which had been incubated for 7 days at $30^{\circ} \mathrm{C}$ ), heated to 70 or $80^{\circ} \mathrm{C}$ for 10 min by immersing the tubes in a water bath, cooled immediately, and incubated at $37^{\circ} \mathrm{C}$ for up to 2 weeks. Spore production was indicated by the development of turbidity in the broth and the subsequent development of growth on EG agar or medium 10 agar after inoculation with the broth culture.

Fermentation products. Strains were grown for 3 days in peptone-yeast extract-Fildes solution-glucose (PYFG) broth (16). Alcohols, volatile acids, and nonvolatile acids were analyzed, for the most part, by the method of Holdeman and Moore (10). Formic acid could not be detected by the method used.

Media and growth conditions for cells in the preparation of DNA. For the preparation of deoxyribonucleic acid (DNA), most organisms were grown at $37^{\circ} \mathrm{C}$ in EG broth with $4 \%$ (vol/vol) Fildes solution (16) and $0.5 \%$ (wt/vol) glucose added. Three strains, $\mathrm{F} \# 6, \mathrm{~F} \# 10$, and $\mathrm{CH}-\mathrm{C}-41$, were grown in prereduced EG broth. Cells were harvested by centrifugation in the late logarithmic phase and were washed twice with distilled water and once with $0.15 \mathrm{M} \mathrm{NaCl}-0.1 \mathrm{M}$ ethylenediaminetetraacetic acid (pH 8.0). For preparation of tritium-labeled DNA, the organisms were grown in prereduced EG broth supplemented with about $5 \mu \mathrm{Ci}$ of $\left[\right.$ methyl $\left.-{ }^{3} \mathrm{H}\right]$ thymidine per $\mathrm{ml}$ (The Radiochemical Centre Ltd., Amersham, England).

Preparation of DNA. DNA was prepared by the Marmur method (21) modified to include phenol extraction steps in place of the chloroform-isoamyl alcohol deproteinization treatment (31). At least two steps of each of phenol, ribonuclease, and isopropyl alcohol treatments and one step of Pronase (Kaken Chemical Co. Ltd., Tokyo; $1 \mathrm{mg} / \mathrm{ml}$ ) treatment were included. Ribonucleic acid in the crude DNA solution was digested at $37^{\circ} \mathrm{C}$ for $30 \mathrm{~min}$ by addition of $40 \mu \mathrm{g}$ of ribonuclease A (Sigma Chemical Co.) per $\mathrm{ml}$, which was preheated at $80^{\circ} \mathrm{C}$ for $10 \mathrm{~min}$ to destroy deoxyribonuclease. DNA finally precipitated by isopropyl alcohol on a glass rod was washed successively in ethyl alcohol solutions of increasing concentration $(70,80$, 90 , and $99 \%$ [vol/vol]), each for 10 to $30 \mathrm{~min}$ with occasional gentle stirring by hand, and dissolved in $0.2 \times \mathrm{SSC}$ (SSC $=0.15 \mathrm{M} \mathrm{NaC} 1$ plus $0.015 \mathrm{M}$ trisodium citrate, $\mathrm{pH} 7.0$ ) after drying in air. Turbidity of the DNA solution, if any, was reduced by repeated centrifugation at $15,000 \mathrm{rpm}$ for $30 \mathrm{~min}$. The DNA purity was assessed from the $230 \mathrm{~nm} / 260 \mathrm{~nm}$ extinction ratio (21). DNA thus prepared was found to contain less than $10 \%$ RNA determined by the orcinol reaction (23) and less than $5 \%$ protein detected by the method of Lowry et al. (20). The amount of DNA was deter- mined by the method of Burton (2), using calf thymus DNA (Worthington Biochemicals Corp., Freehold, N.J.) as a standard.

DNA base composition. The guanine-plus-cytosine $(\mathrm{G}+\mathrm{C})$ content of the DNA was determined by the methods of Marmur (21) and Marmur and Doty (22), using an automatic recording spectrophotometer (Komatsu Electronics, Tokyo). The DNA from calf thymus was included in each set of analyses as a standard; the $\mathrm{G}+\mathrm{C}$ content of the calf thymus was regarded as $42 \mathrm{~mol} \%$.

Preparation of DNA filter (disk DNA). The DNA filter was prepared by the method of Gillespie and Spiegelman (5) with partial modification. An appropriate amount of DNA in $0.2 \times \mathrm{SSC}$, about $50 \mu \mathrm{g}$ per filter, was denatured by heating to $100^{\circ} \mathrm{C}$ for 10 min and quickly cooling. The DNA solution was adjusted to a final concentration of $50 \mu \mathrm{g} / \mathrm{ml}$ of $2 \times \mathrm{SSC}$ with distilled water and $10 \times \mathrm{SSC}$. One milliliter of the adjusted solution was passed at low speed (about 1 $\mathrm{ml} / \mathrm{min}$ ) through a nitrocellulose membrane filter (24 $\mathrm{mm}$ in diameter, $0.45-\mu \mathrm{m}$ pore size; Toyo Roshi Ltd., Tokyo) that had been presoaked in $2 \times$ SSC. The DNA filter was washed with $2 \mathrm{ml}$ of $2 \times \mathrm{SSC}$ at low speed and with $10 \mathrm{ml}$ of $2 \times \mathrm{SSC}$ at moderate speed (about $3 \mathrm{ml} / \mathrm{min}$ ) and dried for $2 \mathrm{~h}$ at room temperature and for $2 \mathrm{~h}$ in a vacuum oven at $80^{\circ} \mathrm{C}$.

DNA-DNA hybridization. DNA-DNA hybridization was carried out as described by Gillespie and Spiegelman (5) with partial modification. $\left[{ }^{3} \mathrm{H}\right] \mathrm{DNA}$ was sheared by ultrasonic disruptor (model UR-200P, Tomy Seiko Co., Ltd., Tokyo) at $140 \mathrm{~W}, 20 \mathrm{kHz}$, for about $3 \mathrm{~s}$ in $5 \mathrm{ml}$ of $1 \times \mathrm{SSC}$ and dissociated at $100^{\circ} \mathrm{C}$ for $10 \mathrm{~min}$ in $0.5 \times \mathrm{SSC}$. The DNA concentration was finally adjusted to a specific activity of about 3,000 $\mathrm{cpm} / \mathrm{ml}$ in $2 \times \mathrm{SSC}$ containing $0.25 \%$ (wt/vol) sodium dodecyl sulfate. One milliliter of this DNA solution (input DNA) was incubated with the disk DNA in a capped, small glass vial at $55^{\circ} \mathrm{C}$ for $20 \mathrm{~h}$ with occasional gentle shaking by hand. At the end of incubation, the filter was washed by filtration with $2 \mathrm{ml}$ of $2 \times$ SSC and then with $5 \mathrm{ml}$ of $5 \mathrm{mM}$ tris(hydroxymethyl)aminomethane-hydrochloride buffer (pH 9.0) at moderate speed. The washed filter was dried under an infrared lamp and placed in $10 \mathrm{ml}$ of scintillation fluid containing $4 \mathrm{~g}$ of 2,5-diphenyloxazole and $0.1 \mathrm{~g}$ of 1,4bis[2-(5-phenyloxazolyl)]-benzene per liter of toluene. The amount of input DNA bound to the disk DNA was estimated by counting the radioactivity of the membrane filter, using a liquid scintillation counter (Packard model 3330). The DNA homology was represented as the homology index, i.e., the percentage of input DNA bound to a certain disk DNA relative to the homologous reaction.

Dissociation of hybrid DNA. The thermal dissociation assay was carried out by the method of Nakamura et al. (28). A DNA-DNA hybrid was formed on a membrane filter as described above, except that 1 ml of annealing mixture with 6,000 instead of 3,000 cpm was used. The filter on which the hybrid duplex was formed was punched into small disks $(10 \mathrm{~mm}$ in diameter) which were transfixed with an insect pin and placed in a tube $(13$ by $100 \mathrm{~mm}$ ) containing $1.2 \mathrm{ml}$ of $0.5 \times \mathrm{SSC}$. The tube was then placed in a water bath. The small disks were transfered at 10 -min intervals through a series of tubes with a $5 \mathrm{C}$ degree 
increase at each interval. The water bath reached each new temperature in 2 to $4 \mathrm{~min}$. Each tube was emptied into a scintillation vial and washed with $0.5 \mathrm{ml}$ of $0.5 \times$ SSC. Ten milliliters of a preparation of Triton X-100 counting solution (three parts of the toluene counting solution and two parts of Triton X-100) was added to each vial. The radioactivity of the vial was counted after the vial had been left in the liquid scintillation counter for more than $24 \mathrm{~h}$.

\section{RESULTS}

The characteristics of the 84 strains studied are given in Tables 2 through 4 . The strains were divided into five groups (I, II, III, IV, and $\mathrm{V})$ on the basis of cellular morphology, carbohydrate fermentation, and $\mathrm{G}+\mathrm{C}$ content. The groups were considered to differ from each other at the species level. This differentiation of groups was substantiated by the results of DNA homology assays; the homology indexes among strains of the five groups were less than $65 \%$. Except for five fresh isolates of groups II and III, all of the strains studied were found to have spores and be heat resistant. Consequently, they were all regarded as sporeformers belonging to the genus Clostridium.

Characters common to all strains. All of the strains studied shared certain features in common. They were all obligately anaerobic, nonmotile, sporeforming, gram-positive rods with rounded ends; they occurred singly, in pairs, and in short or long chains. They had distinctive coiling characteristics, except for the strains of group I, which had a straight form. Cultures on solid or in liquid media, at $48 \mathrm{~h}$ or less, revealed long, tightly or loosely coiled forms with various proportions of semicircular or circular rods and partially coiled elements (Fig. 1C). Old cultures had an increasing number of gram-negative cells. Cells on glucose-blood-liver agar containing a relatively large amount of carbohydrates were larger or stouter than those on EG agar. All of the strains had cells with Y-shaped branching. The branching was not easily observed, but it was often clearly seen with gram-negative, partially autolyzed cells in old ( 3 weeks) cultures. Terminal to subterminal spores were produced in medium 10 agar and/or CM agar slants incu- bated at $30^{\circ} \mathrm{C}$ for 2 weeks. Spore formation was not demonstrated easily, particularly with fresh isolates. Among the media used, the decreasing order of detection of spores was: medium 10 agar $>\mathrm{CM}$ agar slant $\geqq \mathrm{EG}$ agar plate. These strains survived heating at $70^{\circ} \mathrm{C}$ for $10 \mathrm{~min}$, but their resistance to $80^{\circ} \mathrm{C}$ for $10 \mathrm{~min}$ was variable not only between strains but also within strains after incubation on medium 10 agar and/or CM agar slants at $30^{\circ} \mathrm{C}$ for 7 days.

The temperature for optimal growth was $37^{\circ} \mathrm{C}$. No growth usually occurred at $15^{\circ} \mathrm{C}$. Growth in PYG broth (10) was slightly enhanced by the addition of $10 \%$ rumen fluid or both $0.0005 \%$ hemin and $0.00005 \%$ menadione but was not affected by the addition of $0.1 \%$ Tween 80 . Surface colonies on EG agar (2 days) and on medium 10 agar (3 days) were whitish to brownish gray, convex to slightly pulvinate, circular, smooth, shiny, and semiopaque to opaque; they had an entire or slightly erose margin. The colonies were 0.7 to $1.5 \mathrm{~mm}$ in diameter, except those of group I strains, which were larger (3.0 to $4.0 \mathrm{~mm}$ ).

Group I. Group I consisted of 51 strains, including $C$. ramosum strains ATCC 25582, VPI 8546, and VPI 4496A, with straight form (Fig. 1A).

Cells on EG agar (2 days old) measured 0.4 to 0.6 by 0.8 to $13.0 \mu \mathrm{m}$. Long filamentous forms were often observed, particularly in media containing $1 \%(\mathrm{vol} / \mathrm{vol})$ detergent Triton X-100. Coiled forms were not detected. The fresh isolates frequently stained gram negative, especially at initial isolation. No, or only slight, growth occurred in PYF broth. PYFG cultures had moderate to abundant growth, usually with a smooth sediment.

All the strains of this group readily formed round, terminal spores $(0.6 \mu \mathrm{m}$ in diameter) in cultures on EG agar plates as well as on medium 10 agar and $\mathrm{CM}$ agar slants.

The G+C contents of the DNAs from ATCC 25582, VPI 8546, VPI 4496A, A2-E3, R16-12, and MO101-3 were 28.8, 27.9, 28.4, 28.2, 28.6, and $28.5 \mathrm{~mol} \%$, respectively. These values were consistent with those reported for the neotype and other strains of $C$. ramosum $(9,10,32)$.

TABLE 2. Positive characteristics of the helically coiled strains studied and of a related organism, Clostrid. ium ramosum

Acetic acid production from PYFG

Acid from glucose

Y-shaped branching of cells

Growth enhancement by: Hemin $(0.0005 \%)$ and menadione $(0.00005 \%)$

Rumen fluid (10\%)

Neutral red reduction

Round, terminal to subterminal spores 
TABLE 3. Negative characteristics of the helically coiled strains studied and of a related organism, Clostridium ramosum ${ }^{\alpha}$

Acid from:
Arabinose
Erythritol
Inositol
Melezitose
Sorbitol
Sorbose
Xylose
Ammonium production
Gas from PYF
Gelatin liquefaction
Growth enhancement by Tween 80 (0.05\%)
Hemolysis
Lactate utilization to propionic acid
Litmus milk digestion
Motility
Nitrate reduction
Production of:
Catalase
Glutamic acid decarboxylase
Hydrogen-sulfide (SIM)
Indole
Lecithinase (EYA)
Products from PYFG:
Butyric acid
Isobutyric acid
Propionic acid
Succinic acid
Valeric acid
Isovaleric acid
Threonine conversion

"SIM, Hydrogen sulfide-indole-motility medium; EYA, McClung-Toabe egg yolk agar (modified) (10).

Group II. Group II included 21 strains with distinctive coiling characteristics. In contrast with the uniformity of group I strains (C. $\mathrm{ra}$ mosum), they had a variety of carbohydrate fermentation patterns from strain to strain (Table 4).

Cells on EG agar (2 days old) measured 0.3 to 0.4 by 1.0 to $5.0 \mu \mathrm{m}$. They showed a preponderance of semicircular to circular forms with a few relatively short helical filaments (Fig. 1B) and sometimes had partially swollen, stout forms $(0.8 \mu \mathrm{m}$ in width) in old cultures. Slight growth occurred in PYF broth. PYFG cultures had moderate to abundant growth, with a smooth to flocculent sediment in 7 days. Round, terminal to subterminal spores $(0.7 \mu \mathrm{m}$ in diameter) were formed by all of the strains of this group except for strains MO-S-2, CH2-3, and CH2-9.

The average $\mathrm{G}+\mathrm{C}$ content of the DNAs from eight strains (E3-1, VPI 8723, I47, I49, I50, R-S1, MO-S-1, and MO-S-3) was $28.0 \mathrm{~mol} \%$.

Group III. Group III consisted of eight coiled strains.

Cells on EG agar (2 days old) measured 0.3 to
0.5 by 2.0 to $10.0 \mu \mathrm{m}$. They were relatively large and long, with various degrees of coiling (Fig. 1C). Cells of strain VPI C28-23-1A were sometimes nearly straight after having been heated to $80^{\circ} \mathrm{C}$ for $10 \mathrm{~min}$ without alteration of any other property; subsequent subcultures did not show coiled cells. Slight growth occurred in PYF broth. PYFG cultures had moderate to abundant growth, with a smooth to flocculent sediment in 7 days. Round, terminal to subterminal spores (about $0.7 \mu \mathrm{m}$ in diameter) were formed by six strains. Two strains, $18 \mathrm{H}-39$ and H17-60 (fresh isolates from humans), neither formed spores nor survived heating at $70^{\circ} \mathrm{C}$ for $10 \mathrm{~min}$.

The average $\mathrm{G}+\mathrm{C}$ content of the DNAs from four strains (VPI C28-23-1A, VPI 8872, 18H-39, and $\mathrm{H} 17-60$ ) was $27.2 \mathrm{~mol} \%$.

Group IV. Group IV consisted of a single strain, VPI C22-44-2 (Eubacterium-AQ) (26), with coiling characteristics.

Cells on EG agar (2 days old) measured 0.3 to 0.4 by 1.5 to $5.0 \mu \mathrm{m}$. A small number of nearly straight cells in chains or in filaments was usually observed among masses of the tightly coiled forms. The diameter of the coiled form was about $1.0 \mu \mathrm{m}$. Slight growth occurred in PYF broth. PYFG cultures had moderate growth, with a smooth to flocculent sediment, sometimes with no turbidity. This strain was the least fermentative of the strains in the five groups. Round, terminal to subterminal spores $(0.7 \mu \mathrm{m}$ in diameter) were seen in old cultures ( 2 weeks old) on medium 10 agar.

The $\mathrm{G}+\mathrm{C}$ content of the DNA from VPI C2244-2 was $35.8 \mathrm{~mol} \%$.

Group V. Group V was comprised of three strains (F\#6, F\#10, and CH-C-41) with coiling characteristics. The former two are the original strains of this sort described by Fitzgerald et al. (4).

No growth usually occurred on EG or glucose-blood-liver agar plates incubated in the steel-wool jar. Moderate growth was obtained on medium 10 agar and on prereduced EG agar plates. Poor growth occurred in prereduced PYF broth, but prereduced PYFG cultures had moderate growth, with a smooth to stringy sediment, mostly without turbidity. Cells on medium 10 agar ( 3 days old) measured 0.3 to 0.4 by 1.5 to $3.0 \mu \mathrm{m}$. Long filaments with tight coils predominated. Round, terminal or subterminal spores (about $0.7 \mu \mathrm{m}$ in diameter) were formed by the three strains in old cultures on medium 10 agar incubated at $30^{\circ} \mathrm{C}$ for 2 weeks (Fig. 1D).

The $\mathrm{G}+\mathrm{C}$ contents of the DNAs were 46.8 , 46.7 , and $45.9 \mathrm{~mol} \%$ for $\mathrm{F} \# 6, \mathrm{~F} \# 10$, and $\mathrm{CH}-\mathrm{C}$ 41 , respectively.

DNA homologies. Table 5 shows the percent homologies among seven $\left[{ }^{3} \mathrm{H}\right] \mathrm{DNAs}$ and $21 \mathrm{un}$ - 


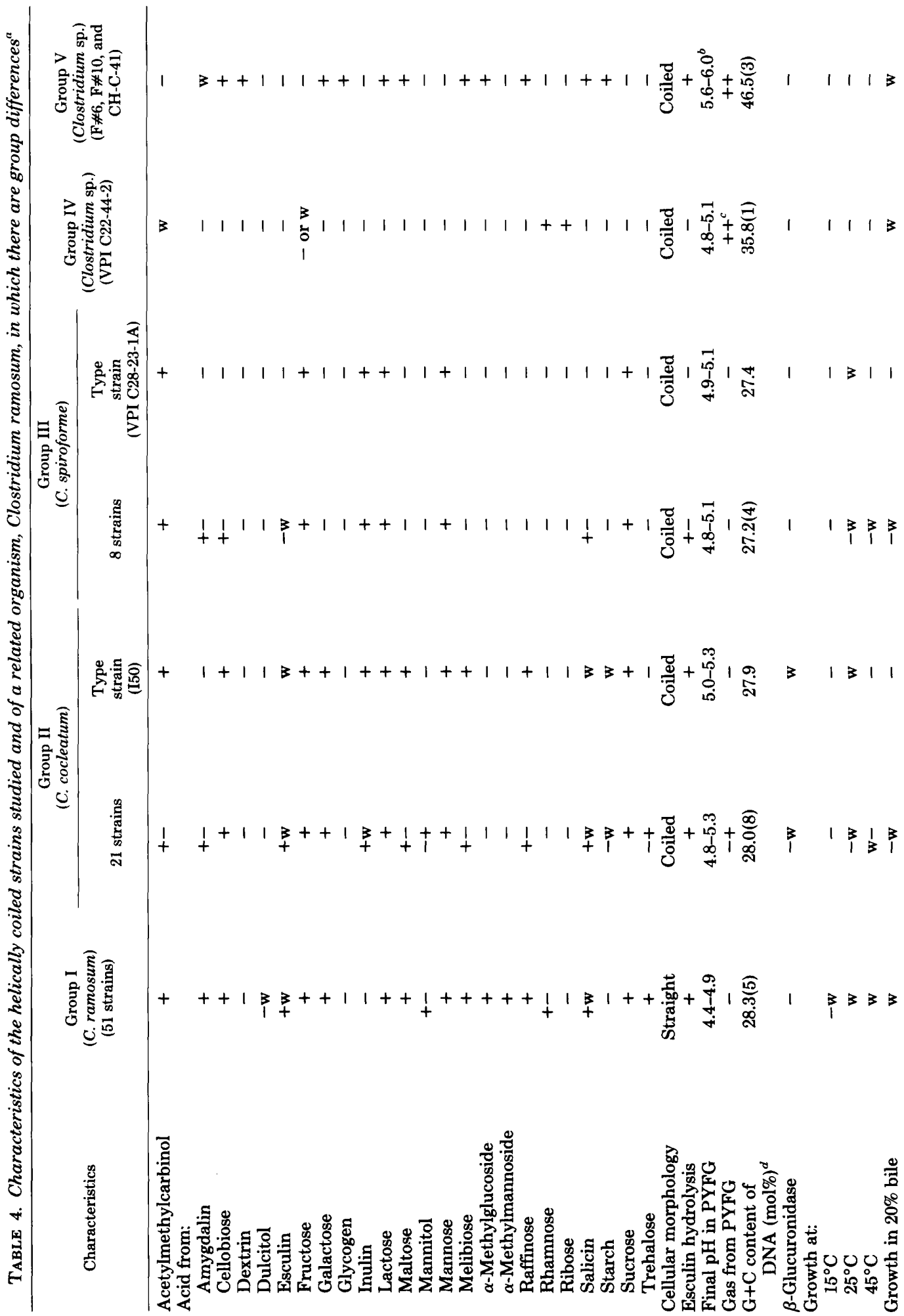




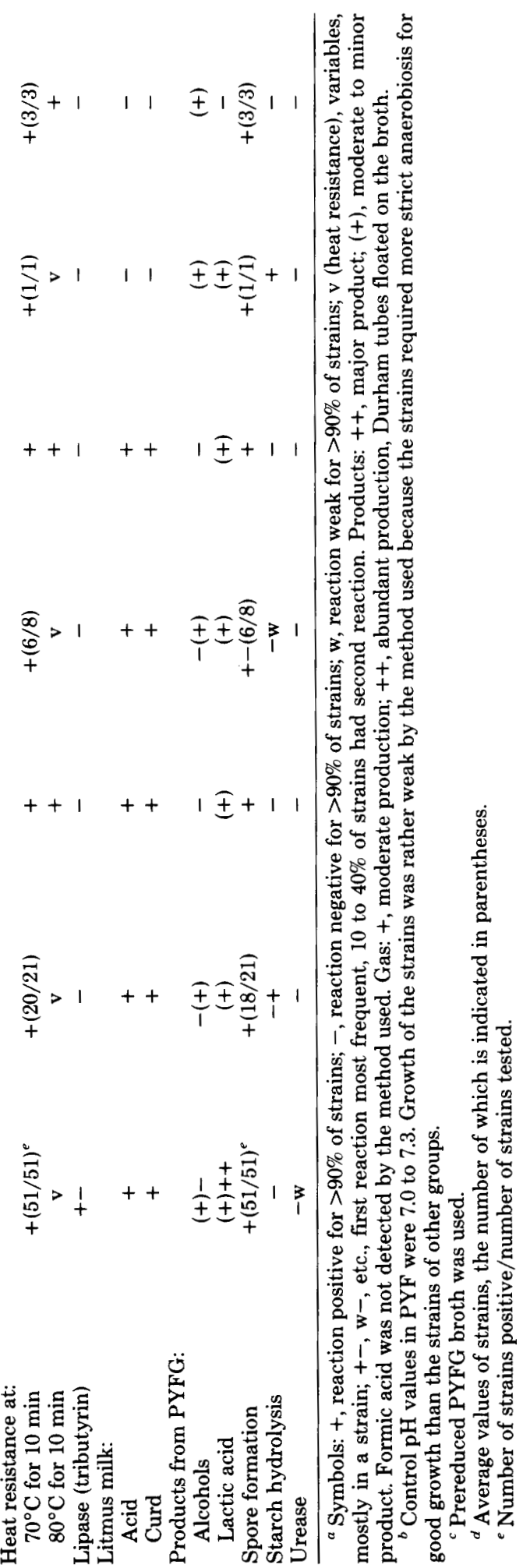

labeled DNAs from representative strains of the five groups. The homologies had essentially the same values by reciprocal determinations in all of the possible combinations of strains. In the homologous reactions, 30 to $60 \%$ reassociation was found and was taken as $100 \%$ relative homology.

The labeled DNA from C. ramosum ATCC 25582 of group I reassociated at high levels (83 to $100 \%$ ) with unlabeled DNAs from strains of the same group, at moderate levels ( 32 to $53 \%$ ) with unlabeled DNAs from strains of groups II and III, and at low levels (1 to $5 \%$ ) with unlabeled DNAs from strains of groups IV and V. Labeled DNAs from three strains (E3-1, I50, and VPI 8723) of group II were bound at high levels ( 75 to $96 \%$ ) with unlabeled DNAs from the same group, at moderate levels ( 35 to 50 and 46 to $61 \%$ ) with unlabeled DNAs from groups I and III, respectively, and at low levels (1 to 5\%) with unlabeled DNAs from strains of groups IV and V. The labeled DNA from strain VPI C28-23-1A of group III was reassociated at high levels (74 to $88 \%$ ) with unlabeled DNAs from the strains of the same group, at moderate levels (45 to 53 and 48 to $56 \%$ ) with unlabeled DNAs from strains of groups I and II, respectively, and at low levels ( 1 to $3 \%$ ) with unlabeled DNAs from the strains of groups IV and V. Group IV strain VPI C22-44-2 and group V strain F\#10 showed low degrees of homology with one another ( 1 to $5 \%$ ) and with the strains of groups I, II, and III (1 to $5 \%$ ).

The two fresh isolates of group III, $18 \mathrm{H}-39$ and $\mathrm{H} 17-60$, which had neither spores nor were resistant, exhibited high degrees of homology ( 88 and $85 \%$, respectively) to the sporeforming reference strain VPI C28-23-1A of the same group.

Thermal dissociation profile of hybrid DNA. The thermal dissociation profiles of hybrid DNA duplexes formed between several combinations of DNAs are shown in Fig. 2. The thermal elution midpoints of the hybrid DNA formed between group I strains ATCC 25582 (labeled DNA) and A2-E3 (unlabeled DNA) and between group II strains I50 (labeled DNA) and VPI 8723 (unlabeled DNA) were about 73 and $72^{\circ} \mathrm{C}$, respectively. The thermal elution midpoint of the heterologous duplex formed between the labeled DNA of ATCC 25582 (group I) and the unlabeled DNA of VPI 8723 (group II; homology index, $52 \%$ ) was about $8 \mathrm{C}$ degrees lower than that of the duplex formed between group I strains ATCC 25582 and A2-E3. The heterologous duplex formed between the labeled DNA of group II strain I50 and the unlabeled DNA of group III strain VPI C28-23-1A (ho- 

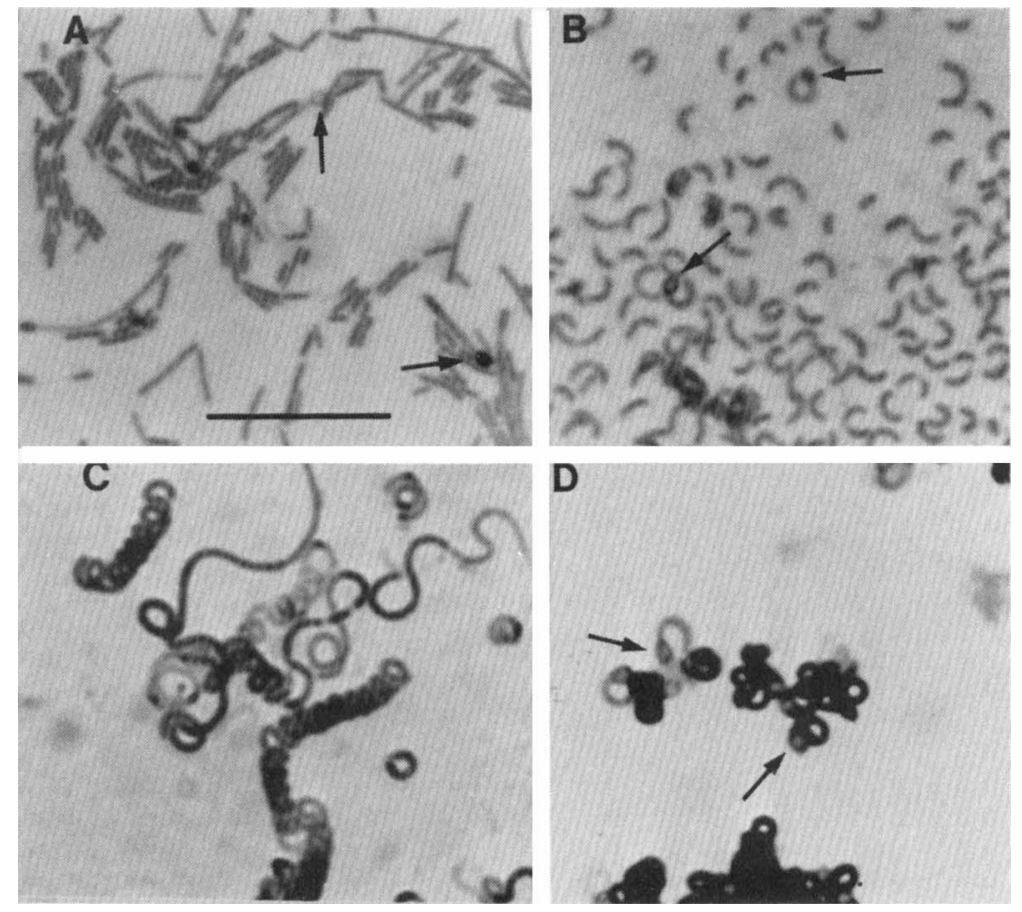

FIG. 1. Photomicrographs of Gram-stained cells of helically coiled microorganisms and Clostridium ramosum. (A) Cells of C. ramosum VPI 8546 (group I) from a 48-h-old EG agar plate; (B) cells of E3-1 (group II, C. cocleatum) from a 2-week-old culture on medium 10 agar; (C) cells of VPI 8872 (group III, C. spiroforme) from a 48-h-old EG agar plate; (D) cells of F\#10 (group V, Clostridium sp.) from a 2-week-old culture on medium 10 agar. Spores or prespore-like swellings are indicated by arrows. Bar represents $10 \mu \mathrm{m}$.

mology index, $63 \%$ ) had a lower thermal elution midpoint (about $65^{\circ} \mathrm{C}$ ) than the hybrid duplexes formed between group I strains ATCC 25582 and A2-E3 and between group II strains I50 and VPI 8723. Thus, it seems that the homology regions of hybrid DNA duplexes among three groups of strains may include more unpaired base sequences than those of the strains of a group. These findings confirmed the appropriateness of differentiating groups I, II, and III from each other even though they have similar $\mathrm{G}+\mathrm{C}$ contents (ca. $28 \%$ ).

\section{DISCUSSION}

The first report of an anaerobic, gram-positive, helically coiled microorganism from the cecum of rats was by Bladen et al. in 1964 (1). Since then, a number of similar organisms have been isolated from the intestines of humans and other animals $(4,6,8,18,19,26,34)$ and from a human abscess (30). Recently, Sugihara et al. (P. T. Sugihara, V. L. Sutter, K. S. Bricknell, and S. M. Finegold, Abstr. Annu. Meet. Am. Soc. Microbiol. 1977, C146, p. 59) isolated 18 strains of this organism from 18 of 135 fecal specimens from adult humans. The mean number of cells per gram (dry weight) of feces was 2 $\times 10^{9}$. In this study, 3 strains from 3 of 22 fecal specimens from adult humans, 3 strains from 2 of 10 cecal specimens from rats, 12 strains from 7 of 15 cecal specimens from mice, and 8 strains from 7 of 21 cecal specimens from chickens were isolated. They were found in amounts of $10^{6}$ to $10^{9}$ cells per gram (wet weight) of feces. Consequently, this particular kind of organism is considered to be distributed in a wide range of animals including humans.

Most authors $(1,4,6,26,34)$ have regarded the coiled organisms as nonsporeformers ( $E u$ bacterium) because of the difficulty of demonstrating their spore formation. The original strain of this sort was, however, isolated by Fitzgerald et al. (4) from specimens heated to $80^{\circ} \mathrm{C}$ for $5 \mathrm{~min}$. Recently, Koopman et al. (19) and Hazenberg et al. (8) observed spores, particularly in vivo, with their strains. In this study, a number of strains were also isolated from the specimens treated with heat, ethyl alcohol, or chloroform. Furthermore, all of the strains of coiled organisms were found to have spores and 
TABLE 5. DNA homologies among four groups of coiled strains and Clostridium ramosum ${ }^{a}$

\begin{tabular}{|c|c|c|c|c|c|c|c|}
\hline \multirow{3}{*}{$\begin{array}{l}\text { Unlabeled } \\
\text { DNA from: }\end{array}$} & \multicolumn{7}{|c|}{ Labeled DNA from: } \\
\hline & \multirow{2}{*}{$\begin{array}{c}\text { Group I } \\
\text { (C. ramosum } \\
\text { ATCC 25582) } \\
\end{array}$} & \multicolumn{3}{|c|}{ Group II } & \multirow{2}{*}{$\begin{array}{c}\text { Group II } \\
(\mathrm{C} 28-23-1 \mathrm{~A})\end{array}$} & \multirow{2}{*}{$\begin{array}{l}\text { Group IV } \\
\text { (C22-44-2) }\end{array}$} & \multirow{2}{*}{$\begin{array}{c}\text { Group V } \\
(\mathrm{F} \# 10)\end{array}$} \\
\hline & & E3-1 & 150 & VPI 8723 & & & \\
\hline \multicolumn{8}{|l|}{ Group I } \\
\hline $\begin{array}{l}\text { C. ramosum } \\
\text { ATCC } 25582\end{array}$ & 100 & 35 & 50 & 38 & 53 & 4 & 2 \\
\hline $\begin{array}{l}\text { C. ramosum } \\
\text { VPI } 8546\end{array}$ & 97 & 41 & 47 & 40 & 51 & 5 & 2 \\
\hline $\begin{array}{l}\text { C. ramosum } \\
\text { VPI 4496A }\end{array}$ & 106 & 38 & 45 & 44 & 49 & 1 & 3 \\
\hline A2-E3 & 92 & 42 & 42 & 36 & 47 & 2 & 2 \\
\hline R16-12 & 91 & 40 & 39 & 39 & 50 & $-b$ & - \\
\hline MO101-3 & 83 & 35 & 38 & 42 & 45 & - & - \\
\hline \multicolumn{8}{|l|}{ Group II } \\
\hline E3-1 & 38 & 100 & 77 & 91 & 47 & 2 & 3 \\
\hline R-S-1 & 41 & 76 & 86 & 84 & 51 & - & - \\
\hline VPI 8723 & 52 & 94 & 96 & 100 & 56 & 2 & 2 \\
\hline I47 & 39 & 82 & 95 & 78 & 52 & 2 & 3 \\
\hline I50 & 43 & 84 & 100 & 89 & 48 & 3 & - \\
\hline $\mathrm{CH} 2-3$ & 40 & 87 & 91 & 75 & 49 & - & - \\
\hline \multicolumn{8}{|l|}{ Group III } \\
\hline VPI C28-23-1A & 53 & 56 & 63 & 58 & 100 & 2 & 3 \\
\hline VPI 8872 & 43 & 60 & 61 & 60 & 87 & 5 & 4 \\
\hline $18 \mathrm{H}-39$ & 32 & 53 & 52 & 54 & 88 & - & 1 \\
\hline H17-60 & 39 & 47 & 48 & 59 & 85 & - & - \\
\hline CH46-27 & 35 & 46 & 50 & 55 & 74 & - & - \\
\hline \multicolumn{8}{|l|}{ Group IV } \\
\hline VPI C22-44-2 & 1 & 3 & 1 & 2 & 2 & 100 & 5 \\
\hline \multicolumn{8}{|l|}{ Group V } \\
\hline$F \# 6$ & 3 & 5 & 2 & 1 & 1 & 3 & 96 \\
\hline F\#10 & 5 & 2 & 3 & 2 & 3 & 4 & 100 \\
\hline $\mathrm{CH}-\mathrm{C}-41$ & 2 & 2 & 2 & 1 & 3 & 1 & 83 \\
\hline
\end{tabular}

${ }^{a}$ Most values (given as percentages) were averages of two to three tests.

${ }^{b}$ Not tested.

be heat resistant except for the five fresh isolates of groups II and III. The two nonsporeforming strains of group III, however, showed high degrees of DNA homology with the sporeforming strain VPI C28-23-1A of the same group. It therefore is considered appropriate that all of the coiled organisms are sporeformers and should be placed in the genus Clostridium. These organisms are gram-positive, obligately anaerobic, nonmotile, sporeforming, rod-shaped cells that grow in long chains with tight coils, particularly in young broth cultures; these features distinguish these organisms from the members of the other genera of the family Bacillaceae, viz., Bacillus, Sporolactobacillus, Desulfotomaculum, and Sporosarcina.

All of the strains with cells of straight form were included in a single group (group I) and were identified as members of $C$. ramosum be- cause their overall characteristics conformed closely to those of the neotype strain of $C$. $r a$ mosum-ATCC 25582-and to the current descriptions of $C$. ramosum $(9,10,32)$.

The coiled strains studied were divided into four groups (II, III, IV, and V) at the species level mainly on the basis of carbohydrate fermentation, DNA base composition, and DNA homology. They differ from the previously described species of the genus Clostridium principally in morphology: their tightly coiled cells, particularly in young broth cultures, are rather distinctive. Unlike most clostridia, they do not produce butyric acid as an end product of glucose fermentation (10). They can also be distinguished from the species which do not produce butyric acid (such as $C$. aminovalericum, $C$. histolyticum, C. indolis, C. limosum, C. oroticum, C. putrefaciens, C. ramosum, and C. sphen- 


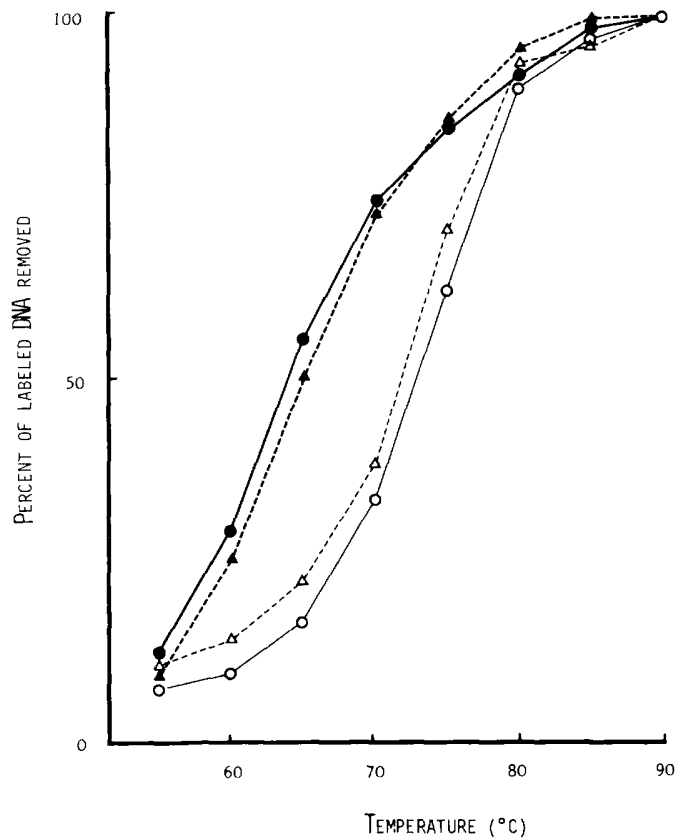

Fig. 2. Thermal dissociation profiles of DNA hybrids. The DNA hybrid duplex was formed by incubation of appropriate amounts of ${ }^{3} \mathrm{H}$-labeled input DNA having a radioactivity of $6,000 \mathrm{cpm}$ with $50 \mu \mathrm{g}$ of unlabeled DNA in $1 \mathrm{ml}$ of $2 \times$ SSC containing $0.25 \%$ (wt/vol) sodium dodecyl sulfate at $55^{\circ} \mathrm{C}$ for $20 \mathrm{~h}$. The hybrid duplex of DNA was dissociated by heating the filter at various temperatures for $10 \mathrm{~min}$ in $1.0 \mathrm{ml}$ of $0.5 \times$ SSC. The dissociated DNA at each temperature was determined by counting the radioactivity as described in the text. Symbols: $O$, hybrid duplex of DNAs from ATCC 25582 (labeled) and A2-E3 (unlabeled); , hybrid duplex of DNAs from ATCC 25582 (labeled) and VPI 8723 (unlabeled); $\triangle$, hybrid duplex of DNAs from I50 (labeled) and VPI 8723 (unlabeled); $\Delta$, hybrid duplex of DNAs from I50 (labeled) and VPI C28-23-1A (unlabeled).

oides), by carbohydrate fermentation, by a number of biochemical properties, and/or by DNA base composition (Table 6) $(10,32)$. Among these organisms, however, C. ramosum shares a number of features in common with the coiled strains of groups II and III such as G+C content of DNA (about 28\%), numerous biochemical properties, and a cellular morphology which sometimes even includes coiling characteristics $(10,26)$. Indeed, Hazenberg et al. (8) identified their coiled strains from mice as members of $C$. ramosum. Their strains may correspond to those of group II or group III rather than groups IV and $\mathrm{V}$ in this study in view of the biochemical features and a $\mathrm{G}+\mathrm{C}$ content of $29.5 \%$ observed by the authors. For these reasons, a number of fresh C. ramosum isolates from the same intes- tinal origin as the coiled organism as well as the neotype strain, ATCC 25582, were included in this study for comparison with other clostridia. In contrast with the uniformity of group I strains (C. ramosum), however, the coiled strains of groups II and III are quite variable in carbohydrate fermentation, differing from each other in five to eight carbohydrate fermentations. This difference was also pointed out by Sugihara et al. (Abstr. Annu. Meet. Am. Soc. Microbiol. 1977, C146, p. 59), Pollock and Rintala (30), and E. P. Cato (Virginia Polytechnic Institute, Blacksburg, Va.; personal communication), who did not consider their coiled strains to be members of $C$. ramosum. Furthermore, DNA homology experiments in this study indicate that groups II and III of coiled strains are clearly different from C. ramosum and from each other. Thus, the two groups of coiled strains represent new species in the genus Clostridium. For the group II strains, we propose the name Clostridium cocleatum (L.n. coclea a whirlpool; M. L. neut. adj. cocleatum in the shape of a whirlpool). The type strain of $C$. cocleatum is I50 (= ATCC $29902=$ NCTC 11210). This strain was isolated from the cecum of mice $\left(10^{8}\right.$ to $10^{10}$ cells per gram [wet weight] of cecal material). For the group III strains, we propose the name Clostridium spiroforme (Gr.n. spira a coil; L.n. forma shape; M. L. neut. spiroforme in the shape of a coil). The type strain of $C$. spiroforme is VPI C28-23-1A (= ATCC $29900=$ NCTC 11211). This strain was isolated from human feces collected at the Virginia Polytechnic Institute, Blacksburg, Va.

The coiled strains of groups IV and V are readily distinguished from one another and from those of groups I, II, and III by their relatively high $\mathrm{G}+\mathrm{C}$ contents and by numerous biochemical properties (Table 6). These distinctions were clearly confirmed by the results of the DNA homology tests (Table 5). They also differ from the presently known clostridia in morphology, a number of biochemical characteristics, and/or $\mathrm{G}+\mathrm{C}$ contents. Table 7 shows the characteristics most useful in distinguishing the two coiled organisms from some clostridia with high $\mathrm{G}+\mathrm{C}$ contents. Accordingly, these organisms are considered as belonging to new species of Clostridium. However, more strains should be studied before the establishment of these new species.

A small number of nearly straight cells was often observed among masses of coiled cells in cultures of some strains. Cells of VPI C28-23-1A once lost their coiling characteristics after heating at $80^{\circ} \mathrm{C}$ for $10 \mathrm{~min}$ without alteration of any other property and never returned to the coiled form thereafter. This might have been a "straight mutant" selected by heat treatment. 
TABLE 6. Characteristics most useful in differentiating the four groups of coiled organism from the Clostridium species which do not produce butyric acid from glucose fermentation ${ }^{a}$

\begin{tabular}{|c|c|c|c|c|c|c|}
\hline \multirow{2}{*}{$\begin{array}{l}\text { Clostridium } \\
\text { species }\end{array}$} & \multirow{2}{*}{$\begin{array}{l}\text { Gelatin } \\
\text { liquefaction }\end{array}$} & \multirow{2}{*}{$\begin{array}{l}\text { Indole } \\
\text { production }\end{array}$} & \multirow{2}{*}{$\begin{array}{l}\text { Nitrate } \\
\text { reduction }\end{array}$} & \multicolumn{3}{|c|}{ Acid from: } \\
\hline & & & & $\begin{array}{l}\alpha \text {-Metyl- } \\
\text { glucoside }\end{array}$ & Lactose & Ribose \\
\hline Group II (C. cocleatum) & - & - & - & - & + & - \\
\hline Group III (C. spiroforme) & - & - & - & - & + & - \\
\hline Group IV (Clostridium sp.) & - & - & - & - & - & + \\
\hline Group V (Clostridium sp.) & - & - & - & - & + & - \\
\hline C. ramosum & - & - & - & + & + & - \\
\hline C. oroticum & - & - & + & - & + & + \\
\hline C. putrefaciens & - & - & - & - & - & - \\
\hline C. sphenoides & - & + & $\mathbf{v}$ & . & + & w- \\
\hline C. indolis & - & + & + & . & $\mathbf{w}$ & - \\
\hline C. limosum & + & - & - & - & - & - \\
\hline C. histolyticum & + & - & - & - & - & - \\
\hline C. aminovalericum & + & - & -+ & - & - & - \\
\hline
\end{tabular}

${ }^{a}$ Data from references 10 and 32 . Symbols: + , positive reaction; - , negative reaction; $v$, variable reaction depending on the strain; $w$, weak reaction;,$-+ w-$, etc., first reaction more than second.

TABLE 7. Characteristics useful in differentiating coiled organisms of groups $I V$ and $V$ from Clostridium species with high $G+C$ contents ${ }^{a}$

\begin{tabular}{|c|c|c|c|c|c|}
\hline \multirow{2}{*}{$\begin{array}{l}\text { Clostridium } \\
\text { species }\end{array}$} & \multirow{2}{*}{$\begin{array}{c}\mathrm{G}+\mathrm{C} \text { content } \\
(\mathrm{mol} \%)\end{array}$} & \multicolumn{4}{|c|}{ Acid from: } \\
\hline & & Fructose & Galactose & Glycogen & Rhamnose \\
\hline Group IV (Clostridium sp.) & 36 & -+ & - & - & + \\
\hline Group V (Clostridium sp.) & 46 & - & + & + & - \\
\hline C. barkeri & 45 & - & - & - & - \\
\hline C. leptum & 51 & -+ & - & - & - \\
\hline C. symbiosum & 46 & + & + & - & - \\
\hline C. nexile & $40-41$ & + & + & - & - \\
\hline C. innocuum & $43-44$ & + & + & - & -+ \\
\hline C. indolis & 44 & + & + & - & -+ \\
\hline C. oroticum & 44 & + & + & - & + \\
\hline C. coccoides & 44 & + & + & - & + \\
\hline C. sphenoides & $41-42$ & + & + & -+ & + \\
\hline C. clostridiiforme & $47-50$ & + & + & -+ & + \\
\hline
\end{tabular}

a Data from references 9, 11 (C. nexile), 15 (C. coccoides), 16 (C. clostridiuforme and C. symbiosum), $27(C$. leptum), and 32. Symbols: + , positive reaction; - , negative reaction; +-, -+ , etc., first reaction more frequent than second.

The reproducibility of this phenomenon was not tested. On the other hand, coiling morphology may be observed in some strains of $C$. ramosum $(10,26)$. Tilby $(33)$ reported that helices predominated among the abnormally shaped cell filaments that occurred in cultures of Bacillus subtilis in media containing chlorpromazine or penicillin and that certain mutants of B. subtilis resistant to the detergent Triton X-100 grew predominantly in a helical form, especially near the end of exponential growth. Therefore, coiling may not always be regarded as a consistent attribute.

On the basis of DNA base composition, two groups are roughly recognizable within the clostridia $(14,32)$ : the one contains strains with a relatively low $\mathrm{G}+\mathrm{C}$ content (21 to $30 \%$ ) and the other contains strains with a high $\mathrm{G}+\mathrm{C}$ content
( 40 to $45 \%$ ) in the DNA. The $\mathrm{G}+\mathrm{C}$ contents $(27$ to $29 \%$ ) of the DNA of the group II and III strains used in this study fell within the lower range and those (46 to $47 \%$ ) of the group V strains were in the higher range. The $\mathrm{G}+\mathrm{C}$ value (35.8\%) of the DNA of strain VPI C22-44-2 (group IV) lies between the two ranges, suggesting the existence of a Clostridium species whose DNA has a base content intermediate in value between these two ranges.

\section{ACKNOWLEDGMENTS}

We are extremely indebted to E. P. Cato and W. E. C. Moore, Virginia Polytechnic Institute and State University, Blacksburg, Va., R. J. Fitzgerald, Veterans Administration Hospital, Miami, Fla., and Y. Morishita, National Institute of Health, Tokyo, for their generous gifts of strains. We also wish to thank E. P. Cato for her helpful taxonomic suggestions and T. Kaneko of our institute and S. Nakamura, Kanazawa 
University, Kanazawa, Japan, for their kindness in providing instruction on DNA homology techniques.

\section{REPRINT REQUESTS}

Address reprint requests to: Choji Kaneuchi, Ph.D., The Institute of Physical and Chemical Research, Wako, Saitama 351, Japan.

\section{LITERATURE CITED}

1. Bladen, H. A., M. U. Nylen, and R. J. Fitzgerald. 1964. Internal structures of a Eubacterium sp. demonstrated by the negative staining technique. J. Bacteriol. 88: 763-770.

2. Burton, K. 1956. A study of the conditions and mechanism of the diphenylamine reaction for the colorimetric estimation of deoxyribonucleic acid. Biochem. J. 62: 315-323.

3. Caldwell, D. R., and M. P. Bryant. 1966. Medium without rumen fluid for nonselective enumeration and isolation of rumen bacteria. Appl. Microbiol. 14: 794-800.

4. Fitzgerald, R. J., J. A. McBride, H. V. Jordan, and B. E. Gustafson. 1965. Helically coiled micro-organism from caecum contents of the rat. Nature (London) 205: 1133-1134.

5. Gillespie, D., and S. Spiegelman. 1965. A quantitative assay for DNA-RNA hybrids with DNA immobilized on a membrane. J. Mol. Biol. 12:829-842.

6. Gordon, J. H., and R. Dubos. 1970. The anaerobic bacterial flora of the mouse cecum. J. Exp. Med. 132: 251-260.

7. Hazenberg, M. P., and L. M. C. Custers-van Lieshout. 1976. Conversion of germ-free mice to the normal state by clostridia. Z. Versuchstierkd. 18:185-190.

8. Hazenberg, M. P., L. M. C. Custers-van Lieshout, W. Engels, and A. C. Kock-van Dalen. 1977. The clostridial flora of conventional mice. Z. Versuchstierkd. 19: 167-174.

9. Holdeman, L. V., E. P. Cato, and W. E. C. Moore. 1971. Clostridium ramosum (Vuillemin) comb. nov.: emended description and proposed neotype strain. Int. J. Syst. Bacteriol. 21:35-39.

10. Holdeman, L. V., and W. E. C. Moore (ed.). 1972. Anaerobe laboratory manual. Anaerobe Laboratory, Virginia Polytechnic Institute and State University, Blacksburg, Va.

11. Holdeman, L. V., and W. E. C. Moore. 1974. New genus, Coprococcus, twelve new species, and emended descriptions of four previously described species of bacteria from human feces. Int. J. Syst. Bacteriol. 24:260-277.

12. Hugo, W. B., and E. G. Beveridge. 1962. A quantitative and qualitative study of the lipolytic activity of single strains of seven bacterial species. J. Appl. Bacteriol. 25: $72-82$.

13. Institute of Medical Science (ed.). 1958. Fundamental methods in bacteriology, p. 124-126. Institute of Medical Science, Tokyo.

14. Johnson, J. L., and B. S. Francis. 1975. Taxonomy of the clostridia: ribosomal ribonucleic acid homologies among the species. J. Gen. Microbiol. 88:229-244.

15. Kaneuchi, C., Y. Benno, and T. Mitsuoka. 1976. Clostridium coccoides, a new species from the feces of mice. Int. J. Syst. Bacteriol. 26:482-486.

16. Kaneuchi, C., K. Watanabe, A. Terada, Y. Benno, and T. Mitsuoka. 1976. Taxonomic study of Bacteroides clostridiiformis subsp. clostridiiformis (Burri and Ankersmit) Holdeman and Moore and related organisms: proposal of Clostridium clostridiiforme (Burri and Ankersmit) comb. nov. and Clostridium symbiosum (Stevens) comb. nov. Int. J. Syst. Bacteriol. 26:195-204.

17. Kent, T. H., L. J. Fischer, and R. Marr. 1972. Glucuronidase activity in intestinal contents of rats and man and relationship to bacterial flora. Proc. Soc. Exp. Biol. 133:303-306.

18. Koopman, J. P., and H. M. Kennis. 1977. Differentiation of bacteria isolated from mouse ceca. Z. Versuchstierkd. 19:174-181.

19. Koopman, J. P., J. P. Van Oeveren, and F. G. J. Janssen. 1973. Use of combusted natural gas to cultivate the anaerobic bacterial flora from the cecum contents of mice. Appl. Microbiol, 26:584-588.

20. Lowry, O. H., N. J. Rosebrough, A. L. Farr, and R. J. Randall. 1951. Protein measurement with the Folin phenol reagent. J. Biol. Chem. 193:265-275.

21. Marmur, J. 1961. A procedure for the isolation of deoxyribonucleic acid from microorganisms. J. Mol. Biol. 3: 208-218.

22. Marmur, J., and P. Doty. 1962. Determination of the base composition of deoxyribonucleic acid from its thermal denaturation temperature. J. Mol. Biol. 5:109-118.

23. Mejbaum, W. 1939. Über die Bestimmung kleiner Pentosemengen, insbesondere in Derivaten der Adenylsäure. Z. Physiol. Chem. 258:117-120.

24. Mitsuoka, T., Y. Morishita, A. Terada, and S. Yamamoto. 1969. A simple method ("plate-in-bottle method") for the cultivation of fastidious anaerobes. Jpn. J. Microbiol. 13:383-385.

25. Mitsuoka, T., T. Sega, and S. Yamamoto. 1965. Eine vervesserte Methodik der qualitativen und quantitativen Analyse der Darmflora von Menschen und Tieren. Zentralbl. Bakteriol. Parasitenkd. Infektionskr. Hyg. Abt. 1 Orig. 195:455-469.

26. Moore, W. E. C., and L. V. Holdeman. 1974. Human fecal flora: the normal flora of 20 Japanese-Hawaiians. Appl. Microbiol. 27:961-979.

27. Moore, W. E. C., J. L. Johnson, and L. V. Holdeman. 1976. Emendation of Bacteroidaceae and Butyrivibrio and descriptions of Desulfomonas gen. nov. and ten new species in the genera Desulfomonas, Butyrivibrio, Eubacterium, Clostridium, and Ruminococcus. Int. J. Syst. Bacteriol. 26:238-252.

28. Nakamura, S., T. Shimamura, H. Hayashi, and S. Nishida. 1975. Reinvestigation of the taxonomy of Clostridium bifermentans and Clostridium sordelli. J. Med. Microbiol. 8:299-309.

29. Parker, C. A. 1955. Anaerobiosis with iron wool. Aust. J. Exp. Biol. Med. Sci. 33:33-38.

30. Pollock, H. M., and L. Rintala. 1977. Unusual coiled gram-positive anaerobe isolated from a gutter wall abscess. J. Clin. Microbiol. 6:642-644.

31. Saito, H., and K. Miura. 1963. Preparation of transforming deoxyribonucleic acid by phenol treatment. Biochim. Biophys. Acta 72:619-629.

32. Smith, L. DS., and G. Hobbs. 1974. Genus III. Clostridium Prazmowski 1880, p. 551. In R. E. Buchanan, and N. E. Gibbons (ed.), Bergey's manual of determinative bacteriology, 8th ed. The Williams \& Wilkins Co., Baltimore.

33. Tilby, M. J. 1977. Helical shape and wall synthesis in a bacterium. Nature (London) 266:450-452.

34. Wensinck, F., and J. G. H. Ruseler-van Embden. 1971. The intestinal flora of colonization-resistant mice. J. Hyg. 69:413-421. 